\title{
ONSET OF CRACK INITIATION IN UNIAXIAL AND TRIAXIAL COMPRESSION TESTS OF DOLOMITE SAMPLES
}

\author{
JERZY CIEŚLIK \\ AGH University of Science and Technology, Department of Geomechanics, Civil Engineering and Geotechnics, Kraków, Poland, \\ e-mail: jerzy.cieslik@agh.edu.pl
}

\begin{abstract}
The paper presents results of laboratory investigation and analysis of crack initiation threshold identification of dolomite samples. First, selected methods for determining crack initiation thresholds are briefly described with special attention paid to four methods: crack volume strain method [14], change in Poisson's ratio [8], lateral strain response method [16], and dilatancy method [4]. The investigation performed on dolomite samples shows that for the uniaxial and conventional triaxial compression tests, the above mentioned methods give quite similar values, except for the crack volume strain method. Crack initiation threshold determined by this method has a distinctively lower value than that obtained by the other methods. The aim of the present paper was to review and assess these methods for identifying crack initiation threshold based on laboratory tests of dolomite samples.
\end{abstract}

Key words: onset of crack initiation, laboratory investigations, uniaxial and triaxial compression

\section{INTRODUCTION}

Existing, natural fractures and flaws in the rock sample and created under loading conditions play crucial role in the brittle damage process in uniaxial and triaxial compression tests. Micro and macro fracture process is a random phenomenon, identified as a development of micro cracks, which arranging into groups, causes a formation of macro crack or a certain zone of cracks [15], [18]. Fracture process can be observed as a nonlinear effect visible on stress-strain characteristics in the unconfined and confined tests [2]-[4], [10]. These effects are caused by initial porosity as well as inhomogeneity. Brace et al. [4] and Kwaśniewski [11], [13] show that in the stress-strain characteristics (Fig. 1) one can find thresholds and stages describing:

- crack closure, observed in the axial $\sigma_{1}$ or differential $\left(\sigma_{1}-\sigma_{3}\right)$ stress-axial strain $\varepsilon_{1}$ relation at the beginning of loading process up to its linearity,

- crack initiation or onset of dilatancy (OD), observed in the volumetric strain $\varepsilon_{V}$ characteristic (threshold of relative dilatancy),

- unstable crack growth (TD) understood as threshold of absolute dilatancy, when the volumetric strain $\varepsilon_{V}$ has a maximum value,

- ultimate strength $\sigma_{F}$.

This phenomenon is visible in both unconfined and confined compression tests. Both thresholds play im- portant role in the interpretation of rock behavior and define loading conditions for the stable and unstable crack propagation. Both thresholds are useful for the identification of rock parameters for constitutive models [5], [6], they can be interpreted as precursors of earthquakes, or mining-induced rock bursts [12], [13], and as reported by Andersson et al. [1], can be used to investigate the onset of spalling (cracking) in a fractured rock mass.

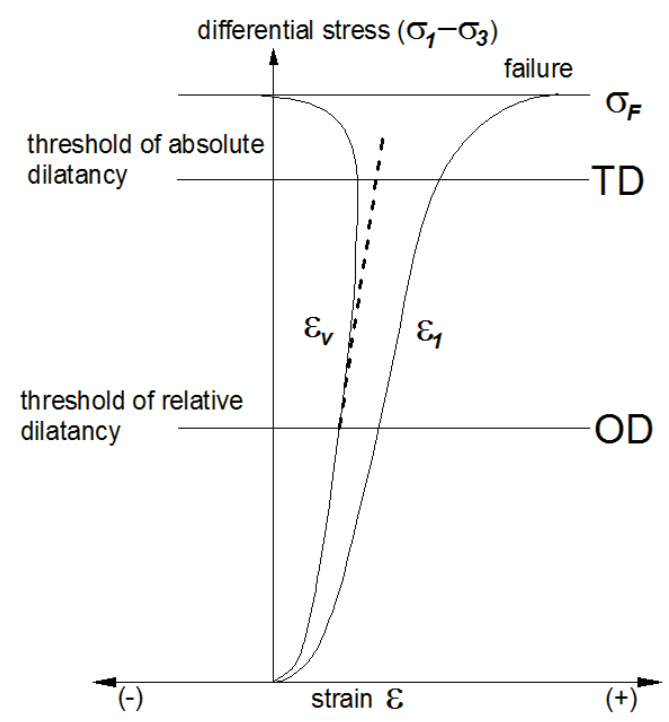

Fig. 1. Idealized stress-strain characteristics with threshold of relative dilatancy (OD), threshold of absolute dilatancy (TD) and failure stress $\left(\sigma_{F}\right)$. Compaction has a positive sign (after Kwaśniewski [11], [13]) 
Identification of unstable crack growth threshold (threshold of absolute dilatancy) makes no difficulty, is unique and precise, but identification of the onset of dilatancy is usually not easy, especially in porous, initially cracked rocks. In last years various authors have proposed different methods for crack initiation threshold identification [16], for example: Martin and Chandler [14] - crack volume strain method; Diederichs [8] - the change in Poisson's ratio as an indicator for establishing crack initiation threshold; Nicksiar and Martin [16] lateral strain response method (LSR), Eberhardt et al. [9] and Diederichs et al. [7] - acoustic emission method.

In this paper, results of the first three methods are compared to the threshold of relative dilatancy obtained for dolomite samples under uniaxial and conventional triaxial loading conditions.

\section{CRACK INITIATION THRESHOLD DETERMINATION}

\subsection{ONSET OF DILATANCY METHOD}

In the case of brittle rocks dilatancy refers to the development of the volume change during the inelastic deformation, under applied deviatoric stress [17]. In brittle rocks it is caused mainly by microcracking but other mechanisms and models are also possible [11].

Crack initiation threshold is visible on the axial (or differential) stress-volumetric strain curve (Fig. 2) when it diverges from the straight line [4]. In practice small deviation of the stress-volumetric strain curve from the straight line can make some difficulties to define one point determining the threshold of relative dilatancy (OD).

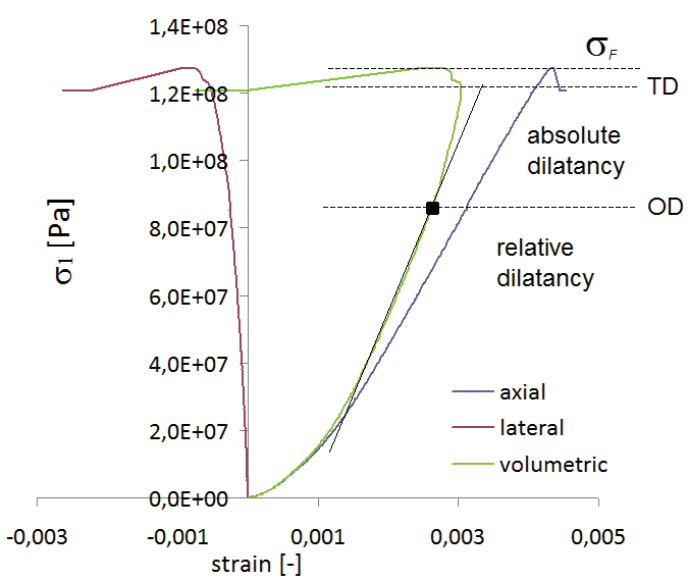

Fig. 2. Axial stress-volumetric strain curve with the threshold of relative (OD) and absolute (TD) dilatancy and failure stress $\sigma_{F}$ for dolomite sample (uniaxial compression case)

\subsection{CRACK VOLUMETRIC STRAIN METHOD (CVS)}

Martin and Chandler [14] proposed that crack initiation could be determined using a plot of crack volumetric strain versus axial strain (Fig. 3). Crack volumetric strain $\varepsilon_{V c r}$ is calculated as a difference of the elastic volumetric strain $\varepsilon_{V e l}$ and volumetric strain $\varepsilon_{V}$ determined in the test,

$$
\begin{gathered}
\varepsilon_{V}=\varepsilon_{1}+2 \varepsilon_{2}, \\
\varepsilon_{V c r}=\varepsilon_{V}-\varepsilon_{V e l},
\end{gathered}
$$

where

$$
\varepsilon_{V e l}=\frac{2 v-1}{E}\left(\sigma_{1}+2 \sigma_{3}\right)
$$

$\varepsilon_{1}, \varepsilon_{2}-$ axial and lateral strain,

$\sigma_{1}, \sigma_{2}=\sigma_{3}-$ axial and confining stress,

$E, v$-Young's modulus and Poisson's ratio.

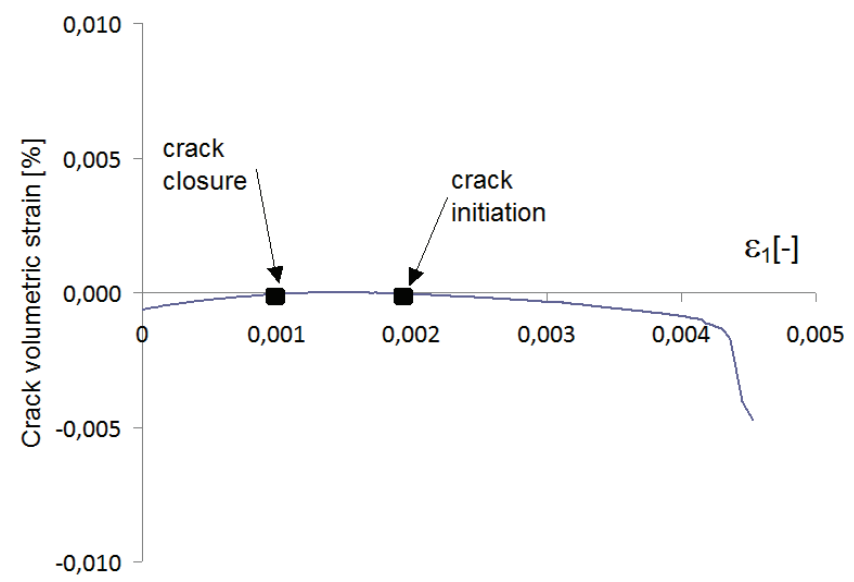

Fig. 3. Crack volumetric strain method for crack initiation threshold determination (uniaxial compression case)

Special care should be taken when Poisson's ratio and Young's modulus are determined for this method [9]. Crack volumetric strain is calculated on the basis of these two elastic constants and is strongly sensitive to its value. This is probably why this method does not give objective values.

\subsection{CHANGE OF POISSON'S RATIO METHOD (PR)}

Diederichs [8] proposed a method of crack initiation threshold identification based on change of 
Poisson's ratio. The onset of crack initiation can be identified by analysis of the relation of Poisson's ratio, evaluated locally, to the log of the axial stress (Fig. 4).

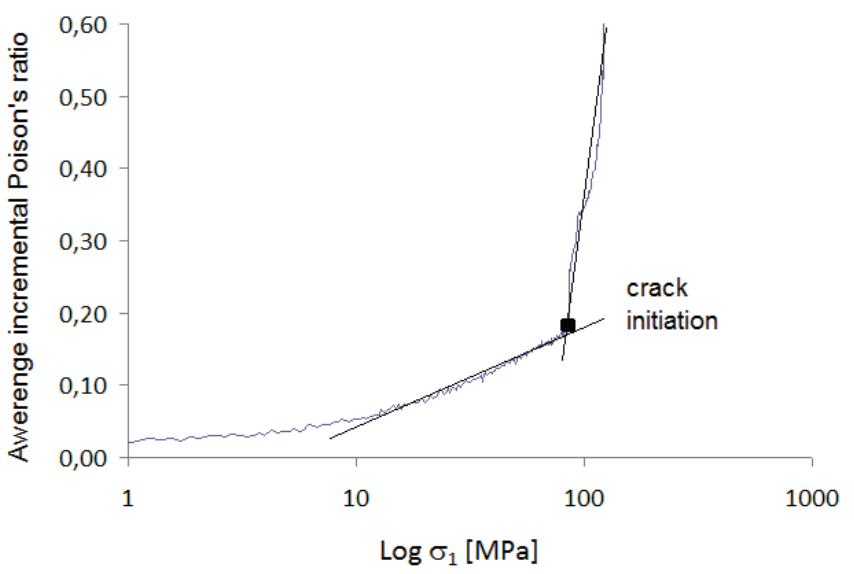

Fig. 4. Poisson's ratio method for crack initiation threshold determination (uniaxial compression case)

\subsection{LATERAL STRAIN RESPONSE METHOD (LSR)}

Following the Nicksiar and Martin [16] the methodology for identification of crack initiation threshold with the LSR method can be described in points:

1. Determine the threshold of absolute dilatancy TD (Fig. 2).

2. Determine the linear lateral strain reference line and plot the axial stress-lateral strain curve (Fig. 5a).

a)

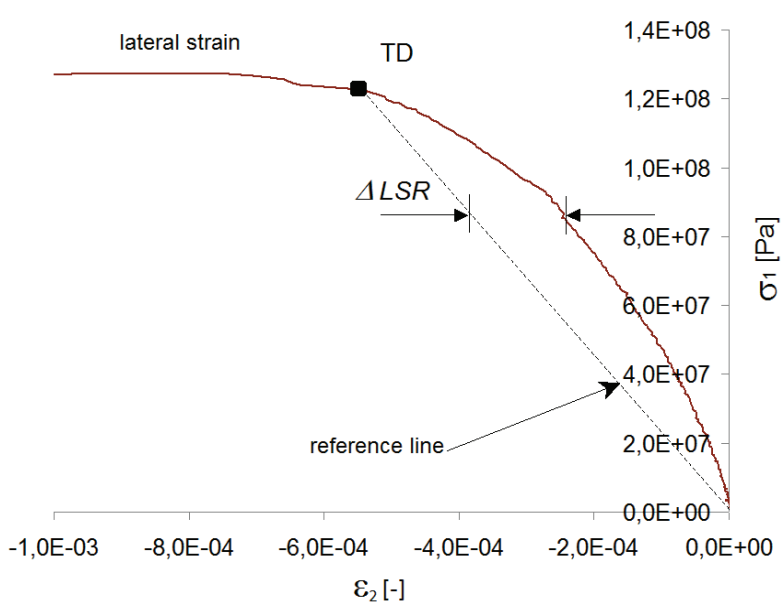

3. Calculate the difference in lateral strain between the loading and linear reference line ( $\Delta \mathrm{LSR})$.

4. Plot the $\Delta$ LSR-axial stress curve (Fig. $5 \mathrm{~b}$ ).

5. Determine the maximum value of the $\Delta \mathrm{LSR}$ and corresponding axial stress (Fig. 5b).

\section{TESTING AND EQUIPMENT DETAILS}

In the present investigation use was made of MTS servo-controlled Rock and Concrete Mechanics Testing System with MTS triaxial cell, model 656.11. The measurement of the axial force was carried out by a force transducer installed inside the pressure cell while the displacements were measured by extensometers. Radial displacements were determined through the measurement of changes of the sample circumference with a chain put around it, axial ones outside the cell, measuring the piston displacement. Twelve cylindrical samples of dolomite $(h=110 \mathrm{~mm}, d=55 \mathrm{~mm})$ from LGOM region (ZG "Lubin") were subjected to compression tests in the pre- and post-failure loading range. Six samples were destined for uniaxial compression $\left(\sigma_{1}>\sigma_{2}\right.$ $=\sigma_{3}=0$ ), and six for conventional triaxial compression tests $\left(\sigma_{1}>\sigma_{2}=\sigma_{3}=p>0\right)$. In the paper, only prefailure loading range results are used for the analysis. The triaxial compression tests were carried out at confining pressures equal to $p=10,20$ and $40 \mathrm{MPa}$. The testing was conducted at room temperature and humidity with the rate of axial strain in all experiments of $5 \times 10^{-5} \mathrm{~s}^{-1}$.

b)

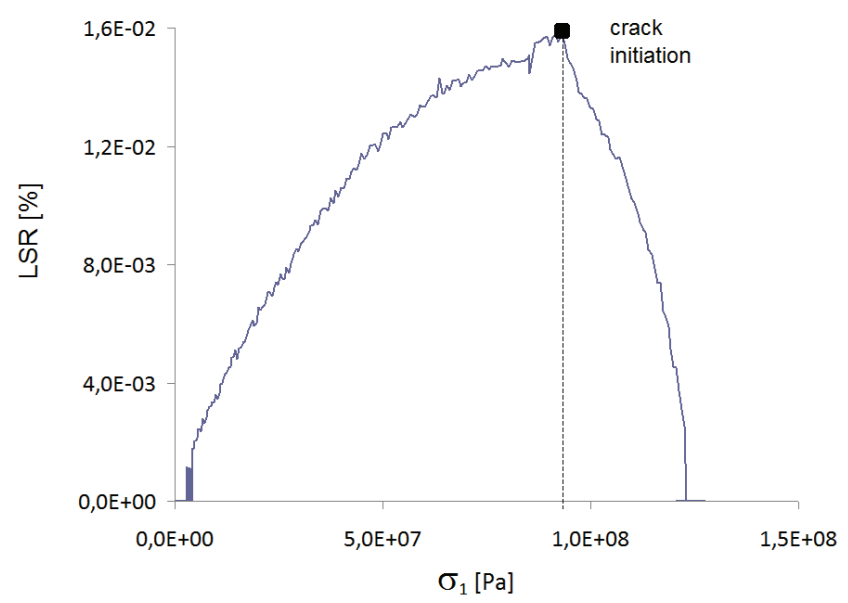

Fig. 5. Methodology of identification of the onset of crack initiation with LSR method (uniaxial compression case) 
4. RESULTS OF THE CRACK INITIATION TRESHOLD IDENTIFICATION
FOR DOLOMITE SAMPLES

Results of the ultimate strength $\sigma_{F}$ and thresholds of the relative OD and absolute TD dilatancy, for confined and unconfined tests are presented in Fig. 6.

In the conventional triaxial compression tests effect of coffining pressure on the ultimate strength $\sigma_{F}$ is clearly visible (Fig. 6a). Ultimate strength of dolomite samples increases, following the rise of the confining pressure value. The threshold of absolute dilatancy (TD) is also dependent on confining pressure similar to the ultimate strength. The values of the dif-

a)

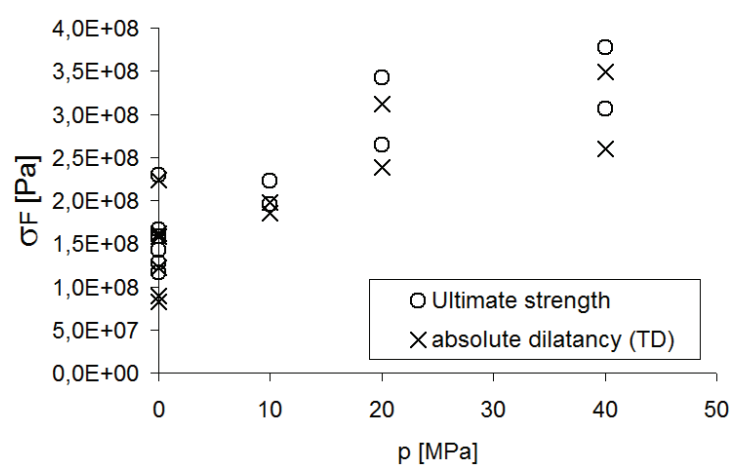

ferential stress corresponding to the threshold of absolute dilatancy (TD) normalized by ultimate strength $\sigma_{F}$ (Fig. 6b) are close to 1 for uniaxial compression tests and 0.9 for confined tests. This means that in the case of uniaxial compression samples failure occurs immediately after absolute dilatancy threshold is reached. Their relative dilatancy threshold is identified as about 0.6 value of ultimate strength in both confined and unconfined tests and has constant value.

For the uniaxial and triaxial compression tests crack initiation threshold determined by all the methods (Fig. 7), excluding results obtained by crack volume strain method (CVS), are in the range $0.4-0.8$ of ultimate strength. Results obtained by dilatancy method (OD) and the lateral strain response method

b)

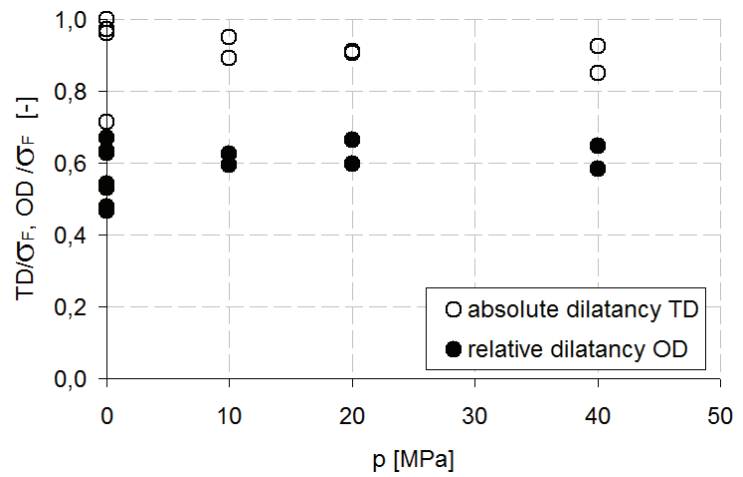

Fig. 6. Effect of confining pressure on the ultimate strength $\sigma_{F}$ and the threshold of relative (OD) and absolute dilatancy (TD)
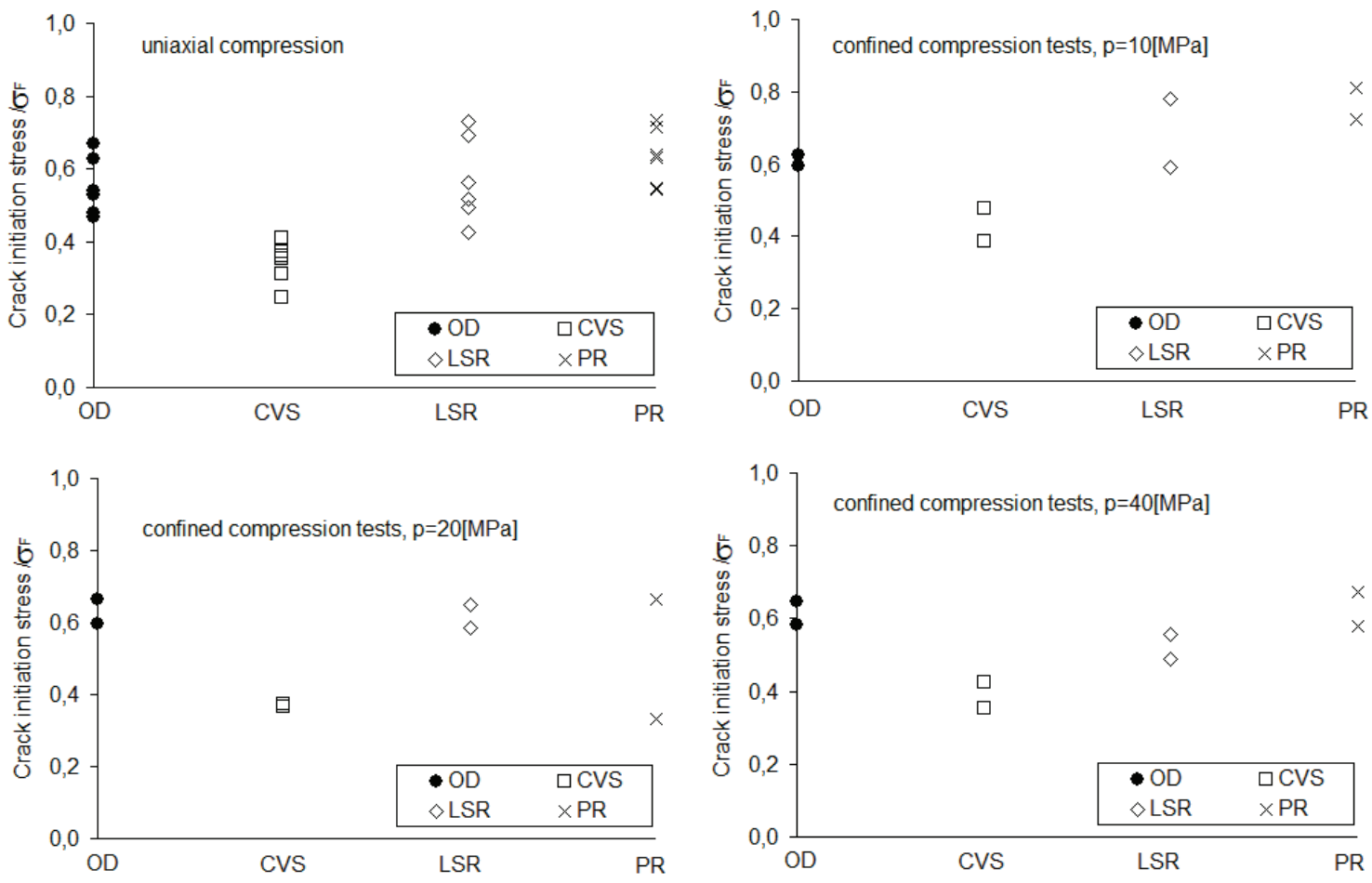

Fig. 7. The onset of crack initiation determined by various methods in uniaxial and triaxial compression tests 
(LSR) are most close to each other (average OD = 0.55 and LSR $=0.57$ for uniaxial compression and $\mathrm{OD}=0.62$ and LSR $=0.61$ for confined tests, with standard deviation less than 0.1). Crack initiation threshold determined by CVS method has usually lower value and is about 0.4 of ultimate strength for unconfined and confined tests. Threshold determined by Poisson's ratio change method (PR) has great value $\mathrm{PR}=0.64$ of ultimate strength for uniaxial compression and $\mathrm{PR}=0.63$ for confined tests.

It should be noted that crack volumetric strain is calculated on the basis of two elastic constants Poisson's ratio and Young's modulus determined for a sample [9]. Their identification, especially Poison's ratio is quite problematic and subjective. This is probably the reason why this method does not give objective values.

\section{CONCLUSIONS}

The paper presents results of the application of four methods of crack initiation threshold determination in uniaxial and triaxial compression tests of dolomite samples.

Identification of unstable crack growth threshold (threshold of absolute dilatancy) usually makes no difficulty and is precise. In the case of the onset of crack initiation (threshold of relative dilatancy) identification is not easy, especially in porous, initially cracked rocks. Results of crack initiation threshold obtained by dilatacy method (OD) and the lateral strain response (LSR) method have similar values, but the LSR method eliminates user's judgment. It could be greatly advantageous for investigation of porous and cracked rocks.

\section{ACKNOWLEDGEMENTS}

This study is sponsored through the statutory research funds of the AGH University of Science and Technology, Faculty of Mining and Geoengineering within the framework of the research program No. 11.11.100.277.

\section{REFERENCES}

[1] Andersson C., Martin C.D., Stille H., The Aspo pillar stability experiment: Part II - rock mass response to coupled excavationinduced and thermal-induced stresses, Int. J. Rock Mech. Min. Sci., 46(5), 2009, 865-878.
[2] Bieniawski Z.T., Mechanism of brittle fracture of rock, Part I - theory of the fracture process, Int. J. Rock Mech. Min. Sci. Geomech. Abstr., 4 (4), 1967a, 395-406.

[3] Bieniawski Z.T., Mechanism of brittle fracture of rock, Part II - experimental studies, Int. J. Rock Mech. Min. Sci. Geomech. Abstr., 4 (4), 1967b, 407-423.

[4] Brace W.F., Paulding B.W. (Jr.), Scholz C., Dilatancy in the fracture of crystalline rocks, J. Geophys. Res., Vol. 71, 1966, 3939-3953.

[5] CIEŚLIK J., Results of triaxial compression tests on LGOM sandstone and dolomite in the context of the elastic-plastic constitutive model selection, Archives of Mining Sciences, 52 (3), 2007, 437-451.

[6] CIEŚLIK J., Plasticity and damage of selected rocks in uniaxial and triaxial compression tests, Rozprawy - Monografie nr 286, Wydawnictwa AGH, 2013 (in Polish).

[7] Diederichs M.S., Kaiser P.K., EBerhardt E., Damage initiation and propagation in hard rock tunnelling and the influence of near-face stress rotation, Int. J. Rock Mech. Min. Sci., 41, 2004, 785-812.

[8] Diederichs M.S., The 2003 Canadian Geotechnical Colloquium: mechanistic interpretation and practical application of damage and spalling prediction criteria for deep tunnelling, Can. Geotech. J., 44, 2007, 1082-1116.

[9] Eberhardt E., Stead D., Stimpson B., Read R.S., Identifying crack initiation and propagation thresholds in brittle rock, Can. Geotech. J., 1998, 35, 222-233.

[10] Hallbauer D.K., Wagner H., CoOK N.G.W., Some observations concerning the microscopic and mechanical behaviour of quartzite specimens in stiff, triaxial compression tests, Int. J. Rock Mech. Min. Sci. Geomech. Abstr., 1973, 20, 713-726.

[11] KWAŚNIEWSKI M., Dylatancja jako zwiastun zniszczenia skaty. Cz. I. Fizykalna istota zjawiska dylatancji, Przegląd Górniczy, 1986a, 42, 2, 42-49.

[12] KWAŚNIEWSKI M., Dylatancja jako zwiastun zniszczenia skały, Cz. II. Mechanizm zjawisk poprzedzajacych zniszczenie, Przegląd Górniczy, 1986b, t. 42, nr 6, 184-190.

[13] KWAŚNIEWSKI M., Mechanical behavior of rocks under true triaxial compression conditions - volumetric strain and dilatancy, Arch. Min. Sci., 2007, Vol. 52, No. 3, 409-435.

[14] Martin C.D., ChAndLeR N.A., The progressive fracture of Lac du Bonnet granite, Int. J. Rock Mech. Min. Sci. Geomech. Abstr., 1994, 31(6), 643-659.

[15] MOORE D.E., LOCKNER D.A., The role of microcracking in shear-fracture propagation in granite, J. Struct. Geol., 1995, $17,5-114$.

[16] NiCKSIAR M., MarTin C.D., Evaluation of Methods for Determining Crack Initiation in Compression Tests on Low-Porosity Rocks, Rock Mech. Rock Eng., 2012, 45, 607-617.

[17] Paterson M.S., Wong T.-F., Experimental Rock Deformation - The Brittle Field, (2nd ed.), Springer Verlag, Berlin Heidelberg, 2005.

[18] Wong T.-F., Micromechanics of faulting in westerly granite, Int. J. Rock Mech. Min. Sci. \&Geomech. Abstr., 1982, Vol. 19, Iss. 2, 143-160. 